\title{
KEPEMIMPINAN KEPALA SEKOLAH BERBASIS NILAI-NILAI LOKAL (Studi Kasus di SMP Negeri 1 Enrekang)
}

\section{THE LOCAL VALUE-BASED LEADERSHIP OF THE PRINCIPAL (A Case Study at SMPN 1 Enrekang)}

KAIRAWAN

SMA Negeri 2 Enrekang, Indonesia

\begin{tabular}{ll}
\hline Keyword & Abstrak \\
\hline \multirow{3}{*}{ Kepemimpnan, } & Rumusan masalah dalam penelitian ini adalah (1) Bagaimanakah penerapan \\
nilai-nilai lokal dalam kepemimpinan kepala SMP Negeri 1 Enrekang? (2) \\
Nilai-Nilai Lokal & Faktor-faktor apakah yang mendukung penerapan nilai-nilai lokal dalam \\
kepemimpinan Kepala SMP Negeri 1 Enrekang? (3) Faktor-faktor apakah \\
& yang menghambat penerapan nilai-nilai lokal dalam kepemimpinan Kepala \\
& SMP Negeri 1 Enrekang?Penelitian ini dimaksudkan untuk mengkaji \\
& implementasi atau penerapan nilai-nilai lokal dalam kepemimpinan kepala \\
& SMP Negeri 1 Enrekang yang meliputi budaya sipakatau, sipakalabbi, dan \\
& sipakainga'.Jenis penelitian ini adalah penelitian kualitatif dengan \\
& menggunakan informan sebagai sumber data. Peneliti sebagai instrumen \\
& dalam pengumpulan data menggunakan tehnik wawancara, observasi dan \\
& studi dokumentasi, data yang diperoleh dianalisis dengan analisis deskriptif \\
& kualitatif. Hasil penelitian ini menunjukkan bahwa implementasi atau \\
penerapan nilai-nilai lokal dalam kepemimpinan Kepala SMP Negeri 1 \\
Enrekang, telah berjalan dengan baik. Hal ini dibuktikan dengan telah \\
diterapkannya nilai-nilai lokal berupa budaya sipakatau, sipakalabbi, dan \\
sipakainga'. Seorang kepala sekolah perlu pula menerapkan tiga gaya \\
kepemimpinan orang Bugis yaitu: (1) rioloi napatiroang, (2) ritengga \\
naparaga-raga, (3) rimunri napampiri. Faktor pendukung ada tiga adalah: (1) \\
masih tertanamnya nilai-nilai lokal dalam kehidupan sehari-hari, (2) adanya \\
sifat kekeluargaan dan kebersamaan, dan (3) adanya sifat tidak diskriminatif. \\
Faktor penghambat penerapan nilai-nilai lokal dalam kepemimpinan kepala \\
SMP Negeri 1 Enrekang adalah terjadinya pergeseran nilai-nilai lokal yang \\
dipengaruhi oleh dampak negatif globalisasi.
\end{tabular}

Local Value, Leadership, The Principal This research aims at examining (1) the implementatioan of local values on the principal's leadership at SMPN 1 Enrekang, (2) the supporting factors on the implementation of local value on the principal's leadership at SMPN 1 Enrekang, and (3) the inhibiting factors on the implementation of local value on the principal's leadership at SMPN 1 Enrekang. The research is a

\#\# HowToCite\#\#

Kairawan. (2017). Kepemimpinan Kepala Sekolah Berbasis Nilai-Nilai Lokal (Studi Kasus di SMP Negeri 1 Enrekang). Edumaspul - Jurnal Pendidikan, 1(1), 88-60 
qualitative with the informants as the data sources. The researcher as the instrument collected the data using interview, observation, and documentation study techniques. Data were then analyzed using qualitative descriptive analysis. The result of the study reveal that the implementation of local values on the principal's leadership at SMPN 1 Enrekang had been conducted well, proved by the implementation of local values such as sipakatau culture, sipakalabbi, and sipakainga'. A principal needs to implement three leadership styles of Bugis as well, namely (1) ri oloi na patiroang, (2) ri tengnga na paraga-raga, and (3) ri munri na pampiri. The supporting factors are (1) there are still the instilment of local values in daily lives, (2) the existence of kinship and togetherness, and (3) nondiscriminative nature. The inhibiting factor of the implementation of local values on the principal's leadership at SMPN 1 Enrekang is the shifting of local values wich influence by negative impact of globalization.

\section{PENDAHULUAN}

Salah satu keunikan dan keunggulan sebuah sekolah adalah memiliki budaya sekolah (school culture) yang kokoh, dan tetap eksis. Perpaduan semua unsur (three in one) baik siswa, guru, dan orang tua yang bekerjasama dalam menciptakan komunitas yang lebih baik melalui pendidikan yang berkualitas, serta bertanggungjawab dalam meningkatkan mutu pembelajaran di sekolah, menjadikan sebuah sekolah unggul dan favorit di masyarakat.

Pada kenyataannya, melalui pengamatan penulis Kepala SMP Negeri 1 Enrekang sebenarnya sudah menerapkan nilai-nilai budaya lokal dalam kepemimpinannya, hal ini terbukti kebijakan-kebijakan beliau diterima baik oleh bawahannya. Dan beliau telah memimpin SMP Negeri 1 Enrekang kurang lebih dua belas tahun yaitu sejak Tahun 2002 sampai sekarang.

Kepemimpinan merupakan salah satu faktor yang sangat penting dalam suatu organisasi karena sebagian besar keberhasilan dan kegagalan suatu organisasi ditentukan oleh kepemimpinan dalam organisasi tersebut.

Terry (Thoha,2010 : 5) mengartikan bahwa Kepemimpinan adalah aktivitas untuk mempengaruhi orang-orang supaya diarahkan mencapai tujuan organisasi. Kepemimpinan meliputi proses mempengaruhi dalam menentukan tujuan organisasi, memotivasi perilaku pengikut untuk mencapai tujuan, mempengaruhi untuk memperbaiki kelompok dan budayanya.

Pemimpin adalah mereka yang menggunakan wewenang formal untuk mengorganisasikan, mengarahkan, mengontrol para bawahan yang bertanggung jawab, supaya semua bagian pekerjaan dikoordinasi demi mencapai tujuan perusahaan. Pemimpin pertama-tama harus seorang yang mampu menumbuhkan dan mengembangkan segala yang terbaik dalam diri para bawahannya. Secara sederhana pemimpin yang baik adalah seorang yang membantu mengembangkan orang lain, sehingga akhirnya mereka tidak lagi memerlukan pemimpinnya itu. 


\section{PEMBAHASAN}

Mulyasa (2007 : 24) Kepala Sekolah merupakan salah satu komponen pendidikan yang paling berperan dalam meningkatkan kualitas pendidikan. Kepala Sekolah adalah penanggung jawab atas penyelenggaraan pendidikan, administrasi sekolah, pembinaan tenaga pendidikan lainnya, pendayagunaan serta pemeliharaan sarana dan prasarana juga sebagai supervisor pada sekolah yang dipimpinnya. Jika dilihat dari syarat guru untuk menjadi Kepala Sekolah, Kepala Sekolah bisa dikatakan sebagai jenjang karier dari jabatan fungsional guru. Apabila seorang guru memiliki kompotensi sebagai Kepala Sekolah dan telah memenuhi persyaratan atau tes tertentu maka guru tersebut dapat memperoleh jabatan Kepala Sekolah.

Thoha (2010 : 49) mengartikan kepemimpinan otokratis sebagai gaya yang didasarkan atas kekuatan posisi dan penggunaan otoritas. Jadi kepemimpinan otokratik adalah kepemimpinan yang dilakukan oleh seorang pemimpin dengan sikapnya yang menang sendiri, tertutup terhadap saran dari orang lain dan memiliki idealisme tinggi.

Wahjosumidjo (2003: 110) pada pembahasan sebelumnya mengemukakan bahwa kepala sekolah harus memiliki karakter yaitu “. keahlian dasar, pengalaman, dan pengetahuan profesional, diklat, dan keterampilan profesional, pengetahuan administrasi dan pengawasan (kompetensi kepala sekolah)".

Sebagai seorang komunikator, Mulyasa (2005: 115) mengemukakan bahwa kemampuan yang harus diwujudkan kepada kepala sekolah sebagai pemimpin dapat dianalisis dari kemampuan berkomunikasi secara lisan terhadap tenaga pendidik, tenaga kependidikan, peserta didik, dan orang tua atau masyarakat serta mampu menuangkan gagasan dan kreatifitasnya dalam bentuk tulisan. Selain itu, dengan adanya komunikasi yang baik antara pemimpin dengan bawahannya akan terjalin hubungan yang harmonis sehingga tercipta iklim atau kondisi yang kondusif untuk mengoptimalkan bakat dan kemampuan yang dimiliki dengan berkarya dan berkreasi sesuai dengan bakat dan kemampuannya.

\section{Nilai-Nilai Budaya Lokal}

Sipakatau adalah konsep dan pandangan yang memandang manusia sebagai manusia. Dalam budaya orang bugis, setiap orang ditekankan untuk memandang dan memperlakukan orang lain selaku manusia seutuhnya. Konsep ini memandang dan menjunjung tinggi orang lain sebagai manusia dengan segala penghargaannya yang ada pada dirinya.

Sipakalabbi adalah konsep yang memandang manusia sebagai makhluk yang memiliki derajat lebih tinggi di banding dengan makhluk ciptaan Tuhan lainnya. Inilah kelebihan manusia yang mestinya harus kita puji dan kita junjung. Menurut konsep dan pemahaman ini, apapun dan bagaimanapun kondisi manusia dengan segala kelebihannya, jelas manusia juga pasti punya kekurangan. Manusia pasti punya kelebihan dan kekurangan.

Sipakainga' adalah sifat dimana kita saling mengingatkan. Apabila ada diantara kita yang melakukan kesalahan apa salahnya kita saling mengingatkan. Dimana dengan tujuan dengan saling mengingatkan kita dapat merubah dan menghindari sifat-sifat tercela yang tidak disukai oleh Allah SWT. Hal yang tak dapat di pungkiri bahwa manusia memiliki kekurangan. Karena tentunya manusia tidaklah sempurna, 
walaupun manusia adalah ciptaan-Nya yang paling sempura di muka bumi ini.

Itulah tiga konsep dasar yang selama ini di junjung tinggi dan dipelihara oleh orang-orang dari suku Bugis (Enrekang) selama mereka bergaul dan berkomunikasi dengan orang lain. Tentunya sebagai warisan budaya-budaya lokal, barangkali sudah sepatutnya hal ini juga kita terapkan dalam kehidupan kita sehari-hari. Termasuk juga ketika kita sementara terlibat perdebatan dan saling mengemukakan pendapat kepada orang lain. Tidak memandang rendah, menghargai, dan saling menasihati kepada orang lain tentunya akan membuat perbedaan pendapat kita jauh lebih berarti. Apalah gunanya berkomunikasi dan berbeda pendapat kalau hanya untuk saling menghina, saling menjatuhkan dan saling caci-maki.

\section{METODE PENELITIAN}

\section{Jenis Penelitian dan Lokasi Penelitian}

\section{Jenis Penelitian}

Penelitian ini menggunakan pendekatan kualitatif yaitu berawal pada data dan bermuara pada kesimpulan (Bungin,2001:18). Sasaran atau obyek penelitian dibatasi agar data yang diambil dapat digali sebanyak mungkin serta agar penelitian ini tidak dimungkinkan adanya pelebaran obyek penelitian, oleh karena itu, maka kredibilitas dari peneliti sendiri menentukan kualitas dari penelitian ini (Bungin,2001:26)

Penelitian ini juga menginterpretasikan atau menterjemahkan dengan bahasa peneliti tentang hasil penelitian yang diperoleh dari informan di lapangan sebagai wacana untuk mendapat penjelasan tentang kondisi yang ada.

\section{Lokasi Penelitian}

Lokasi penelitian adalah SMP Negeri 1 Enrekang Kabupaten Enrekang, yang merupakan salah satu Sekolah Menengah Pertama di Kota Enrekang. SMP Negeri 1 Enrekang didirikan pada Tanggal 23 Agustus 1957, yang terletak di Jalan Jenderal Sudirman No. 3 Enrekang Kecamatan Enrekang Kabupaten Enrekang. Dibangun diatas tanah seluas 6410 M2. Dengan rincian luas bangunan $3.120 \mathrm{M} 2$, luas lapangan basket dan tennis lapangan 360 M2, luas lapangan bola volly 162 M2, luas lapangan takraw dan bulu tangkis 924 M2, dan luas lahan kebun sekolah, kebun toga dan lahan kosong 2.221 M2.

SMP Negeri 1 Enrekang sudah tahun kedua melaksanakan Kurikulum 2013 yang merupakan langkah lanjutan pengembangan Kurikulum Berbasis Kompetensi yang telah dirintis pada tahun 2004 dan KTSP 2006 yang mencakup kompetensi sikap, pengetahuan dan keterampilan secara terpadu.

\section{Fokus dan Deskripsi Fokus Penelitian}

Fokus penelitian ini adalah Kepemimpinan Kepala Sekolah Yang Berbasis Nilai-nilai Lokal (sipakatau, sipakalabbi, sipakainga'). Sedangkan deskripsi fokus pada penelitian ini adalah sebagai berikut :

1. Kepemimpinan berbasis nilai-nilai lokal adalah strategi kepala sekolah dalam mempengaruhi warga sekolah dengan mengedepankan nilai-nilai budaya lokal yaitu; sipakatau, sipakalabbi, sipakainga'.

2. Faktor pendukung kapemimpinan Kepala Sekolah adalah segala sesuatu yang dapat mendukung Kepala Sekolah dalam penerapan nilai-nilai budaya lokal. 
3. Faktor penghambat kepemimpinan Kepala Sekolah adalah segala sesuatu yang dapat menjadi hambatan Kepala Sekolah dalam penerapan nilai-nilai budaya lokal.

\section{Data dan Sumber Data}

Untuk memperoleh data dalam penelitian ini, peneliti menggunakan sumber data dengan teknik Purposive sampling dimana salah satu teknik penentuan sumber data dengan pertimbangan tertentu. Data yang diperoleh dari subyek yang bila diperhatikan maka peneliti membagi menjadi tiga, yaitu:

1. Sumber data penelitian

2. Sumber data dari tempat penelitian adalah tempat yang diamati ketika penelitian, dalam hal ini adalah SMP Negeri 1 Enrekang Kabupaten Enrekang.

3. Sumber data berupa dokumen, yakni arsip-arsip dan data yang berhubungan dengan masalah yang diteliti, dalam hal ini adalah arsip-arsip dan data umum yang berhubungan dengan nilai-nilai budaya lokal; sipakatau, sipakalabbi, dan sipakainga'.

\section{Instrumen Penelitian}

Instrumen utama dalam penelitian ini adalah peneliti sendiri yang terjun langs ung ke lapangan sebagai pengamat dan pewawancara. Sebagai peneliti dan sekaligus sebagai instrumen utama dalam penelitian ini, maka mulai dari perencanaan, pengumpulan, dan analisis data hingga penulisan laporan hasil penelitian seluruhnya dilakukan oleh peneliti sendiri. Sebagai pendukung pelaksanaan penelitian ini digunakan instrumen-instrumen pembantu berupa:
1. Pedoman observasi, digunakan peneliti untuk mengamati penerapan nilai-nilai budaya lokal; sipakatau, sipakalabbi, dan sipakainga' dalam kepemimpinan Kepala SMP Negeri 1 Enrekang

2. Pedoman wawancara, yaitu daftar pertanyaan-pertanyaan pokok yang berkaitan dengan fokus penelitian yang digunakan oleh peneliti dalam melakukan wawancara dengan Kepala sekolah, pengawas, Guru-guru, Tata Usaha, dan orang tua siswa pada SMP Negeri 1 Enrekang dalam hubungannya dengan nilai-nilai budaya lokal yaitu: sipakatau, sipakalabbi, dan sipakainga'.

3. Dokumentasi, yaitu berupa alat pemotretan yang digunakan peneliti dalam mengambil gambar pada Kepala sekolah, pengawas, Guru, Tata Usaha , dan orang tua siswa pada SMP Negeri 1 Enrekang dalam hubungannya dengan nilai-nilai budaya lokal yaitu: sipakatau, sipakalabbi, dan sipakainga'.

\section{Informan dan Sumber Data Penelitian}

Informan penelitian yang dimaksud adalah orang yang dapat memberikan informasi atau keterangan yang berhubungan dengan fokus penelitian. Sedangkan sumber data penelitian ini adalah segala jenis kegiatan dan kejadian yang ditemukan di lapangan yang berhubungan dengan fokus penelitian. Informan dan sumber data penelitian yang ditetapkan adalah; Kepala sekolah, pengawas, guru, Tata Usaha, dan orang tua siswa. Penyambutan siswa dan Guru/Pegawai pada pagi hari digerbang sekolah, memimpin rapat dewan guru dan pada saat memberikan amanat dalam upacara bendera adalah merupakan kegiatan dan kejadian yang mendukung penerapan nilai-nilai lokal 
dalam kepemimpinan kepala SMP Negeri 1 Enrekang.

\section{Teknik Pengumpulan Data}

Pengumpulan data dalam penelitian ini dilakukan dalam tiga tahap. Pada tahap pertama adalah orientasi dilakukan dimana peneliti mengumpulkan data secara umum dan luas yang berkaitan dengan penelitian. Tahap kedua peneliti mengadakan eksplorasi pengumpulan data yang dilakukan lebih terarah sesuai dengan fokus penelitian melalui sumber data atau informan yang kompeten dan mempunyai pengetahuan yang cukup banyak tentang hal yang akan diteliti. Tahap ketiga peneliti melakukan penelitian terfokus, yaitu mengembangkan penelitian eksploratif kepada fokus penelitian berdasarkan kepentingan pengumpulan data secara tepat, cermat, rinci, dan komprehensif. Adapun teknik pengumpulan data yang dilakukan, dibutuhkan sebagai bahan pembuatan laporan penelitian, ada beberapa teknik, cara atau metode yang dilakukan oleh peneliti dalam penelitian ini adalah observasi, wawancara, dan dokumentasi serta disesuaikan dengan jenis penelitian kualitatif.

\section{Teknik Analisis Data}

Teknik analisis data dalam penelitian kualitatif akan dilakukan pada saat pengumpulan data berlangsung, dan setelah selesai pengumpulan data dalam periode tertentu. Pada saat wawancara, peneliti sudah melakukan analisis terhadap jawaban yang diwawancarai setelah dianalisis belum memuaskan, maka peneliti akan melanjutkan pertanyaan lagi, sampai tahap tertentu diperoleh data yang dianggap kredibel. Data dianalisis terlebih dahulu diolah secara ringkas dan sistematis (menulis hasil pengamatan, wawancara, rekaman, dan dokumentasi, selanjutnya mengklasifikasi, mereduksi, dan menyajikan).

\section{Teknik Keabsahan Data}

Setiap peneliti memerlukan standar untuk melihat derajat kepercayaan atau kebenaran setiap hasil penelitian (keabsahan data). Dalam penelitian ini, standar keabsahan data dilakukan dengan uji kredibilitas, salah satu cara uji kredibilitas data yang dilakukan adalah dengan triangulasi, dimana triangulasi terdiri dari triangulasi sumber dan triangulasi teknik pengumpulan data, yang dapat dijelaskan seperti di bawah ini :

1. Triangulasi sumber, untuk menguji kredibilitas data dilakukan peneliti dengan mengecek data yang telah diperoleh melalui beberapa sumber, yaitu melakukan wawancara kepada beberapa informan yang memiliki kedekatan dan mengetahui keadaan yang diteliti, seperti pengawas, wakil kepala sekolah, Guru, Tata Usaha, dan orang tua siswa. Dimana membandingkan data yang diperoleh dari informan yang berbeda seperti data hasil wawancara dengan kepala sekolah dibandingkan dengan hasil wawancara dengan pengawas, wakil kepala sekolah, Tata Usaha dan guru bersangkutan, tujuannya untuk melihat apakah data tersebut saling mendukung atau saling bertolak belakang. Jika data dari informan penelitian ini sesuai dengan data yang diperoleh dari informan lain, maka data tersebut memiliki tingkat kepercayaan yang tinggi, sehingga tingkat kebenaran kesimpulan akhir hasil penelitian dapat dipertanggungjawabkan. 
2. Triangulasi metode atau triangulasi teknik, dengan membandingkan hasil penelitian yang diperoleh melalui wawancara dengan data yang diperoleh melalui pengamatan. Setelah peneliti memperoleh data dari informan melalui wawancara, maka peneliti melakukan pengamatan pada setiap kesempatan pertemuan antara peneliti dan informan. Pengamatan diupayakan tidak diketahui dan disadari oleh informan, agar tingkah laku yang tampak sesuai dengan fakta yang sebenarnya, dan apabila terdapat ketidaksesuaian antara hasil pengamatan dan hasil wawancara, maka peneliti akan melanjutkan mencari data pada pertemuan berikutnya.

3. Member chek, yaitu kegiatan yang berupa penyimpulan secara bersama dengan setiap informan, setelah melakukan wawancara, hal ini dilakukan dalam rangka menghindari kesalahan persepsi antara peneliti dengan sumber data.

\section{HASIL PENELITIAN}

\section{Gambaran penerapan nilai-nilai lokal dalam kepemimpinan kepala SMP Negeri 1 Enrekang}

Penyajian data dalam penelitian ini mengacu pada pedoman wawancara yang merupakan instrumen utama dalam menjawab permasalahan yang diajukan dalam rumusan masalah. Data yang disajikan merupakan data tentang "Kepemimpinan Kepala Sekolah Berbasis Nilai-Nilai Lokal" (Studi Kasus di SMP Negeri 1 Enrekang Kabupaten Enrekang)

Dalam mengimplementasikan kepemimpinan kepala sekolah berbasis nilainilai lokal di SMP Negeri 1 Enrekang
Kabupaten Enrekang dapat diketahui melalui hasil wawancara dengan DMS (wawancara, 17 September 2014) yang saya temui di ruang kepala sekolah, beliau mengatakan bahwa: "Dalam menerapkan kepemimpinan berbasis nilai-nilai lokal, maka setiap pemimpin sebaiknya harus memahami tiga gaya kepemimpinan orang bugis yaitu "Rioloi napatiroang, Rintengngai naparaga-raga, dan Rimunri napampiri”. Hal ini diharapkan agar seorang pemimpin mampu mensinerjikan antara gaya kepemimpinan secara umum dengan gaya kepemimpinan orang bugis. Selain itu seorang pemimpin juga diharapkan dalam kepemimpinannya harus mampu menerapkan nilai-nilai budaya lokal yaitu "Sipakatau, Sipakalabbi, dan Sipakainga'.

Sejalan dengan hal tersebut di atas, ALC (wawancara, 22 September 2014) mengatakan bahwa:" Penerapan nilai-nilai lokal dalam kepemimpinan kepala SMP Negeri 1 Enrekang tetap mencirikan gaya kepemimpinan budaya Bugis. Dan gaya kepemimpinan budaya Bugis tidak bertentangan dengan segala gaya kepemimpinan yang ada seperti gaya kepemimpinan, otokratik, permisif, dan demokratis, karena gaya kepemimpinan ini dapat dimunculkan dan dilaksanakan pada situasi dan kondisi yang berbeda".

Rimunri napampiri artinya seorang pemimpin harus mampu mendorong orangorang yang diasuhnya berjalan di depan dan sanggup bertanggung jawab. Mengacu pada arti tersebut di atas, maka seorang pemimpin harus bisa menjadi penggerak dan motivator, serta mampu bertanggung jawab.

Berikut hasil wawancara dengan SRA (Wawancara, 22 September 2014) yang saya temui di ruang Guru, mengatakan bahwa : 
Kepala SMP Negeri 1 Enrekang Kabupaten Enrekang merupakan sosok pemimpin yang demokratis, segala kebijakan yang diambil senantiasa diketengahkan dalam pertemuanpertemuan atau rapat dewan guru. Saran dan masukan dari bawahan (guru dan staf TU) didengarkan dengan seksama setelah itu barulah diambil sebuah keputusan. Sehingga apa yang menjadi keputusan kepala sekolah dapat diterima baik oleh semua bawahannya.

Dari hasil wawancara dengan NRL (wawancara, 22 September 2014) mengatakan bahwa:

Kepemimpinan kepala sekolah dari dimensi sipakalabbi telah dimiliki dan diimplementasikan oleh Kepala SMP Negeri 1 Enrekang. Hal ini terlihat pada perlakuannnya terhadap bawahan atau siswa yang mempunyai kelebihankelebihan, dengan cara memberikan reward atau penghargaan terhadap setiap kelebihan atau prestasi yang diperoleh oleh Guru, pegawai, dan siswa yang ada di sekolah.

Dari hasil wawancara dengan ALC (wawancara, 13 Oktober 2014) mengatakan bahwa:

Kepemimpinan kepala sekolah telah menerapkan nilai-nilai lokal sipakainga'. Hal tersebut terlihat dari kepribadian kepala sekolah yaitu terbuka terhadap bawahan, murah hati, berani mengakui kekurangannnya di depan bawahannya. Berdasarkan kepribadian tersebut maka bawahan pada umumnya segan terhadap pimpinan. Dan tidak jarang kepala sekolah senantiasa mengingatkan kepada kita akan segala tugas dan tanggung jawab.
Sipakainga' atau sipanginggarrang memang sangat penting, setiap orang mempunyai tanggung jawab untuk saling mengingatkan. Sebagai makhluk sosial kita harus menyadari bahwa kita adalah merupakan bagian dari orang lain. Sehingga apabila diantara kita ada yang butuh bantuan dan berbuat salah, maka berikanlah bantuan serta peringatilah untuk tidak berbuat salah dengan cara yang santun dan lemah lembut.

\section{Gambaran faktor pendukung penerapan nilai-nilai lokal dalam kepemimpinan kepala SMP Negeri 1 Enrekang}

Penerapan nilai-nilai lokal dalam kepemimpinan kepala SMP Negeri 1 Enrekang tentunya terdapat faktor pendukung.

Dari hasil wawancara dengan DMS kepala SMP Negeri 1 Enrekang (wawancara, 17 September 2014) beliau mengatakan bahwa: dalam menerapkan nilai-nilai lokal pada kepemimpinan kepala sekolah tidak dapat dipungkiri bahwa terdapat faktor pendukung yakni; masih tertanamnya nilai-nilai lokal dalam kehidupan sehari-hari, adanya sifat kekeluargaan dan kebersamaan, serta sifat tidak membeda-bedakan dalam perlakuan.

Dari data beberapa informan di atas, maka dapat disimpulkan bahwa gambaran faktor pendukung implementasi atau penerapan nilai-nilai lokal dalam kepemimpinan kepala SMP Negeri 1 Enrekang adalah tiga antara lain: 1) masih tertanamnya nilai-nilai lokal dalam kehidupan sehari-hari, 2) adanya sifat kekeluargaan dan kebersamaan, dan 3) sifat tidak membeda-bedakan dalam perlakuan. 


\section{Gambaran faktor penghambat penerapan nilai-nilai lokal dalam kepemimpinan kepala SMP Negeri 1 Enrekang}

Sejalan dengan perkembangan zaman dan diikuti dengan perkembangan ilmu pengetahuan dan teknologi, bersamaan dengan itu arus globalisasi memberi pengaruh yang cukup besar terhadap pelestarian dan sekaligus pergeseran nilainilai lokal. Dan faktor penghambat penerapan nilai-nilai lokal dalam kepemimpinan kepala SMP Negeri 1 Enrekang adalah terjadinya pergeseran nilainilai lokal yang dipengaruhi oleh dampak negatif globalisasi.

Dari hasil wawancara dengan SDM (wawancara, 22 September 2014) mengatakan bahwa:

Penerapan nilai-nilai lokal di sekolah cukup mengalami hambatan akibat dampak negatif globalisasi, fenomena ini terlihat dengan munculnya watak dan karakter yang terkadang cenderung menyimpang dari ketentuan dan peraturan yang berlaku di sekolah. Sehingga dalam menyikapi persoalan ini kepala sekolah senantiasa menyampaikan kepada bawahan untuk lebih ekstra dalam mengatasi fenomena tersebut, agar fenomena tersebut tidak sampai merusak citra sekolah.

Dari hasil wawancara tersebut di atas dapat dipahami bahwa faktor-faktor penghambat penerapan nilai-nilai lokal dalam kepemimpinan kepala sekolah adalah dengan adanya dampak negatif globalisasi yang memberi pengaruh yang cukup besar terhadap penerapan nilai-nilai lokal yang ada di SMP Negeri 1 Enrekang.

Secara umum kita pahami bahwa globalisasi yang telah melanda, pasti akan membawa dampak bagi segala bidang kehidupan manusia, baik yang bersifat negatif maupun yang bersifat positif. Bahkan, ketika mereka diam sekalipun globalisasi tetap akan melanda karena globalisasi sudah ada di depannya. Oleh karena itu, kita harus jeli dan sekaligus mempersiapkan diri semaksimal mungkin untuk bisa memilih secara cerdas implikasi dari arus globalisasi yang melanda kehidupan kita, dimana pun kita berada. Dampak negatif globalisasi yang dapat mengakibatkan terjadinya pergeseran nilai, tetap kita harus terima sebagai tantangan dan sekaligus pelajaran, untuk selanjutnya kita berusaha mencarikan solusi. Dan siswasiswi yang yang terkenah pengaruh negatif globalisasi perlu dilakukan pembinaan secara intensif, agar mereka tidak lagi melakukan perbuatan-perbuatan menyimpang dari peraturan dan ketentuan yang berlaku.

Dari hasil penelitian yang telah dipaparkan, maka selanjutnya akan diuraikan pembahasan hasil penelitian sebagai berikut:

\section{Penerapan nilai-nilai lokal dalam kepemimpinan kepala SMP Negeri 1 Enrekang}

\section{a. Sipakatau}

Dari beberapa hasil wawancara tersebut di atas dapat dijelaskan bahwa dalam mengidentifikasi masalah penerapan nilai-nilai lokal dalam kepemimpinan kepala SMP Negeri 1 Enrekang dilakukan karena hal ini dapat memberikan gambaran tentang situasi yang terjadi di dalam lingkungan sekolah. Dan pada prinsipnya sifat sipakatau, adalah konsep yang memandang setiap manusia sebagai manusia. Seorang kepala sekolah hendaklah memperlakukan 
siapapun sebagai manusia seutuhnya, sehingga tidaklah pantas memperlakukan orang lain diluar perlakuan yang pantas bagi manusia. konsep ini memandang manusia dengan segala penghargaannya. Siapapun dia dengan kondisi sosial apapun dia, dengan kondisi fisik apapun dia, dia pantas diperlakukan selayaknya manusia. Seorang kepala sekolah sudah seyogyanya memperlakukan manusia lain dengan segala hak-hak yang melekat pada dirinya sebagai manusia. Dan seorang kepala sekolah harus senantiasa memandang manusia lain sebagai mana ia memandang dirinya sebagai samasama manusia.

Penerapan budaya sipakatau dalam lingkungan sekolah tidak terlepas daripada penerapan budaya sipakatau yang ada di dalam lingkungan keluarga. Pembahasan ini menguraikan tentang bagaimana orang tua sebagai pendidik paling awal dalam keluarga, mampu menerapkan budaya sipakatau kepada anak-anaknya. Diharapkan peran orang tua dapat memberi pemahaman tentang menghargai dan menghormati orang lain dalam harkat dan martabatnya sebagai manusia, sehingga dapat memotivasi anak untuk selalu berusaha berbuat dan berprilaku untuk saling menghargai dan menghormati, tolong menolong dan kasih mengasihi sesama manusia mengangkat derajat dan harga diri sebagai generasi penerus.

Adapun penerapan budaya sipakatau di lingkungan sekolah adalah merupakan kelanjutan dari penerapan budaya sipakatau yang ada di dalam lingkungan keluarga. Sebagaimana kita ketahui bahwa sekolah adalah tempat menimbah ilmu untuk bekal masa depan, yang merupakan sebagai tumpuan harapan bagi bangsa dan Negara. Penerapan budaya sipakatau di lingkungan sekolah akan memicu semangat dan motivasi generasi muda untuk senantiasa berprilaku baik dalam meningkatkan prestasi dan semangat untuk terus maju menggapai cita-cita dalam mewujudkan manusia seutuhnya.

Penerapan budaya sipakatau' tidak hanya di lingkungan keluarga dan lingkungan sekolah, melainkan juga termasuk lingkungan masyarakat. Setiap orang dalam berinteraksi di masyarakat, senantiasa dibatasi oleh aturan dan tata krama yang berlaku baik berdasarkan pada nilai-nilai budaya lokal maupun pada ketentuan umum yang telah disepakati bersama. Penerapan budaya sipakatau di arena umum bagi kaum remaja dan generasi muda merupakan aplikasi dari perilaku yang mencerminkan penghargaan dan penghormatan antar sesama, yang senantisa menjunjung tinggi harkat martabat manusia.

\section{b. Sipakalabbi}

Sejalan dengan hasil wawancara tersebut dapat dipahami bahwa sipakalabbi sebagai sifat pemimpin yang ideal, karena pada prinsipnya yang namanya pemimpin harus tanggap terhadap segala fenomena yang ada di dalam wilayah kepemimpinannya. Sipakalabbi, adalah konsep yang memandang manusia sebagai mahluk yang senang dipuji dan diperlakukan dengan baik, diperlakukan dengan selayaknya. Karena itu sebagai seorang pimpinan tentunya tidak akan memperlakukan manusia lain dengan seadanya, tetapi ia cenderung memandang manusia lain dengan segala kelebihannya. Setiap orang mempunyai kelemahan dan kelebihan. Untuk setiap kelebihan manusia sepantasnyalah untuk diberikan reward atau penghargaan. Dan sikap saling memuji akan menciptakan suasana yang menyenangkan dan menggairahkan, hingga siapapun yang 
berada dalam kondisi tersebut akan senang dan bersemangat. Sifat sipakalabbi akan membuat siapapun akan menikmati hidup sebagai suatu keindahan.

\section{c. Sipakainga'}

Berdasarkan hasil wawancara tersebut di atas, dapat dipahami bahwa budaya sipakainga' pengaruhnya sangat besar terhadap kepemimpinan. Hal ini disadari bahwa tidak ada manusia yang sempurna. Setiap manusia memiliki kelebihan dan kekurangan, kita adalah manusia tentu adakalanya kita terpeleset.

Dalam kondisi inilah setiap pemimpin diharapkan agar saling mengingatkan, dan saling memberi peringatan. Siapapun yang berbuat salah akan diperingatkan tentang perbuatannya yang salah tersebut. Sehingga siapapun akan selalu diingatkan untuk berjalan di jalan yang lurus. Tidak ada orang yang bebas dari peraturan. Di dalam suku Bugis peraturan dikenal dengan istilah ade'. Ade' telah dibuat dan disepakati yang bertujuan untuk mengatur tata hubungan dan peran serta fungsi masing-masing komponen masyarakat dan siapapun yang melanggarnya akan mendapatkan sanksi. Bahkan seorang raja sekalipun jika perbuatannya tidak melindungi dan menolong rakyatnya tidaklah pantas ia menjabat sebagai raja. Budaya kritik bukanlah budaya tabu bagi orang bugis, bahkan ia menjadi kebutuhan.

Budaya sipakainga' akan dapat memberikan kontrol pada diri setiap orang, tidak memandang apakah dia pimpinan atau bawahan. Karena setiap orang tidak ada jaminan bagi dirinya untuk tidak berbuat salah. Sehingga sangat diharapkan kepada setiap orang agar dapat membudayakan untuk berani mengakui kesalahan atau kekurangan. Bagi yang mempunyai kekuasaan untuk selalu diingatkan akan kekuasaannya. Demikian halnya bagi seorang pimpinan atau kepala sekolah tentu diharapkan untuk senantiasa memberikan keteladanan bagi bawahan mengenai hal tersebut.

\section{Faktor pendukung penerapan nilai- nilai lokal dalam kepemimpinan kepala SMP Negeri 1 Enrekang}

Faktor pendukung yang paling utama dalam mempengaruhi penerapan nilai-nilai lokal dalam kepemimpinan kepala sekolah adalah kekeluargaan dan kebersamaan. Karena dengan sifat kekeluargaan dan kebersamaan tersebut akan memberi pengaruh yang besar terhadap persatuan dan kesatuan serta keharmonisan seluruh warga sekolah.

Dari data beberapa informan di atas, maka dapat disimpulkan bahwa gambaran faktor pendukung implementasi atau penerapan nilai-nilai lokal dalam kepemimpinan kepala SMP Negeri 1 Enrekang adalah tiga antara lain: 1) masih tertanamnya nilai-nilai lokal dalam kehidupan sehari-hari, 2) adanya sifat kekeluargaan dan kebersamaan, dan 3) sifat tidak membeda-bedakan dalam perlakuan.

\section{Faktor penghambat penerapan nilai- nilai lokal dalam kepemimpinan kepala SMP Negeri 1 Enrekang}

Sejalan dengan perkembangan zaman dan diikuti dengan perkembangan ilmu pengetahuan dan teknologi, bersamaan dengan itu arus globalisasi memberi pengaruh yang cukup besar terhadap pelestarian dan sekaligus pergeseran nilainilai lokal. Dan faktor penghambat 
penerapan nilai-nilai lokal dalam kepemimpinan kepala SMP Negeri 1 Enrekang adalah terjadinya pergeseran nilainilai lokal yang dipengaruhi oleh dampak negatif globalisasi.

Dewasa ini bangsa Indonesia berada dalam era modernisasi dan globalisasi. Arus informasi yang begitu cepat merambah keberbagai lapisan masyarakat dan tidak terkecuali kaum remaja, sehingga berbagai budaya dari luar dapat merubah pola pikir dan cara pandang mereka dalam berbuat dan bertingkah laku. Berbagai aspirasi dan kepentingan baik individu maupun kelompok banyak yang tersalurkan tidak sesuai dengan norma-norma hukum dan etika yang menjunjung nilai-nilai budaya dan harkat sebagai manusia. Maraknya perkelahian dan tawuran antar pelajar dewasa ini merupakan salah satu dampak kurangnya pemahaman remaja akan nilainilai budaya sipakatau, yaitu tidak menghargai dan menghormati harkatnya sebagai manusia. Oleh sebab itu perlu ada penanaman nilai-nilai dan norma-norma sipakatau kepada generasi muda atau kaum remaja, agar terhindar dari pengaruh negatif atau perilaku yang tidak sesuai dengan nilainilai budaya yang merupakan jati diri orang Bugis.

Secara umum kita pahami bahwa globalisasi yang telah melanda, pasti akan membawa dampak bagi segala bidang kehidupan manusia, baik yang bersifat negatif maupun yang bersifat positif. Bahkan, ketika mereka diam sekalipun globalisasi tetap akan melanda karena globalisasi sudah ada di depannya. Oleh karena itu, kita harus jeli dan sekaligus mempersiapkan diri semaksimal mungkin untuk bisa memilih secara cerdas implikasi dari arus globalisasi yang melanda kehidupan kita, dimana pun kita berada.
Dampak negatif globalisasi yang dapat mengakibatkan terjadinya pergeseran nilai, tetap kita harus terima sebagai tantangan dan sekaligus pelajaran, untuk selanjutnya kita berusaha mencarikan solusi atau jalan keluar. Dan siswa-siswi yang sudah terkenah pengaruh negatif globalisasi perlu dilakukan pembinaan secara intensif, agar mereka tidak lagi melakukan perbuatan-perbuatan yang menyimpang dari peraturan dan ketentuan yang berlaku.

\section{KESIMPULAN}

Berdasarkan hasil penelitian dan pembahasan tentang gambaran Kepemimpinan kepala sekolah berbasis nilai-nilai lokal di SMP Negeri 1 Enrekang, dapat disimpulkan sebagai berikut :

1. Penerapan nilai-nilai lokal dalam kepemimpinan Kepala SMP Negeri 1 Enrekang Kabupaten Enrekang, telah berjalan dengan baik. Hal ini dibuktikan dengan telah diterapkannya nilai-nilai lokal berupa budaya sipakatau: konsep yang memandang setiap manusia sebagai manusia. Seorang kepala sekolah hendaklah memperlakukan siapapun sebagai manusia seutuhnya, sehingga tidaklah pantas memperlakukan bawahan diluar perlakuan yang pantas bagi manusia. Dan seorang kepala sekolah harus senantiasa memandang manusia lain sebagai mana ia memandang dirinya sebagai sama-sama manusia. Sipakalabbi: konsep yang memandang manusia sebagai mahluk yang senang dipuji dan diperlakukan dengan baik, diperlakukan dengan selayaknya. Karena itu sebagai seorang pimpinan tentunya tidak akan memperlakukan manusia lain dengan 
seadanya, tetapi ia cenderung memandang manusia lain dengan segala kelebihannya. Setiap orang mempunyai kelemahan dan kelebihan. Untuk setiap kelebihan manusia sepantasnyalah untuk diberikan reward atau penghargaan. dan sipakainga': Karena setiap orang tidak ada jaminan bagi dirinya untuk tidak berbuat salah. Sehingga sangat diharapkan kepada setiap orang agar dapat membudayakan untuk berani mengakui kesalahan atau kekurangan. Demikian halnya bagi seorang pimpinan atau kepala sekolah tentu diharapkan untuk senantiasa memberikan keteladanan bagi bawahan mengenai hal tersebut. Dan seorang kepala sekolah perlu menerapkan gaya kepemimpinan Bugis yaitu rioloi napatiroang, ritengga naparaga-raga, rimunri napampiri.

2. Faktor pendukung penerapan nilai-nilai lokal dalam kepemimpinan kepala SMP Negeri 1 Enrekang adalah tiga antara lain: (1) masih tertanamnya nilai-nilai lokal dalam kehidupan sehari-hari, (2) adanya sifat kekeluargaan dan kebersamaan, dan (3) adanya sifat tidak diskriminatif.

3. Faktor penghambat penerapan nilai-nilai lokal dalam kepemimpinan kepala SMP Negeri 1 Enrekang adalah terjadinya pergeseran nilai-nilai lokal yang dipengaruhi oleh dampak negatif globalisasi.

\section{DAFTAR PUSTAKA}

[1] Abdullah, Hamid, 1990. Reaktualisasi Etos Budaya Manusia Bugis, Ramadhani, Solo.

[2] Arikunto, Suharsimi. 1990. Manajemen Pengajaran Secara Manusiawi. Jakarta : PT. Rineka Cipta.
[3] Arikunto, Suharsimi. 1999. Prosedur Penelitian Suatu Pendekatan Praktek (Edisi Revisi IV). Jakarta: PT. Rineka Cipta.

[4] Bungin, Burhan. 2001. Metodologi Penelitian Kualitatif. Jakarta : PT. Raja Grafindo Persada.

[5] Chris Rowley, Keith Jackson. 2012. Manajemen Sumber Daya Manusia: The Key Concepts. Jakarta : PT Raja Grafindo Persada,

[6] Departemen Pendidikan Nasional. 2008. Kamus Besar Bahasa Indonesia Pusat. Jakarta: PT. Gramedia Pustaka Utama

[7] Fathoni, Abdurahmat. 2006. Organisasi dan Manajemen Sumber Daya Manusia. Jakarta : PT. Rineka Cipta

[8] Hasibuan, Malayu, S.P. 2007. Manajemen Sumber Daya Manusia. Jakarta : Bumi Aksara.

[9] Kartini, Kartono. 2010. Pemimpin dan Kepemimpinan. Jakarta : Rajawali Pers.

[10] Mangemba, 1988. Mengenal Jiwa Orang Bugis Makassar dari dekat. Ujung Pandang: Yayasan Kebudayaan Sulawesi Selatan

[11] Mattulada. 1993. Manajemen Tradisional Dalam Kalangan Usahawan Orang Bugis Makassar, Lontara No. 17. Ujung Pandang : Universitas Hasanuddin

[12] Moein, Andi. 1990. Menggali Nilainilai Budaya Bugis Makassar dan Sirik Na Pacce. Ujungpandang: Mapres

[13] Mulyasa. 2012. Kurikulum Berbasis Sekolah. Konsep, Strategi dan Implementasi. Bandung: PT. Remaja Rosdakarya 
[14] Nashir, Haedar. 2013. Pendidikan Karakter Berbasis Agama dan Budaya. Yogyakarta: Multi Presindo

[15] Rahim, A. Rahman. 1985. Nilai Utama Kebudayaan Bugis. Ujung Pandang : Lembaga Penerbitan Universitas Hasanuddin

[16] Rohiat.2008. Kecerdasan Emosional Kepemimpinan Kepala Sekolah. Bandung : PT. Refika Aditama

[17] Rohiat. 2010. Manajemen Sekolah. Bandung : PT. Refika Aditama

[18] Rosmiati, Tati dkk. 2009. Manajemen Pendidikan. Bandung : Alfabeta

[19] Said, Natsir. 1964. Ammatowa; Salah Satu Manifestasi kebudayaan Indonesia Makassar. Jakarta: Djambatan

[20] Soekarno, K. 1986. Dasar-dasar Manajemen. Jakarta: Puswara
[21] Suhendra, K. 2008. Manajemen dan Organisasi Dalam Realita Kehidupan. Bandung : CV. Mandar Maju.

[22] Thoha, Miftah. 2010. Kepemimpinan Dalam Manajemen. Jakarta : Rajawali Pers

[23] Universitas Negeri Makassar. 2012. Pedoman Penulisan Tesis dan Desertasi. Makassar : Badan Penerbit UNM.

[24] Punagi, Andi. 1988. Bingkisan Budaya Sulawesi Selatan. Ujung Pandang : Yayasan Kebudayaan Sulawesi Selatan

[25] Wahjosumidjo. 2011. Kepemimpinan Kepala Sekolah Tinjauan Teoritik dan Permasalahannya. Jakarta : PT. Raja Grafindo Persada.

[26] Wahyudi.2012. Kepemimpinan Kepala Sekolah Dalam Organisasi Pembelajaran. (Learning Organization). Bandung: Alfabeta. 